\title{
Gene-circuit therapy on the horizon: Synthetic biology tools for engineered therapeutics*
}

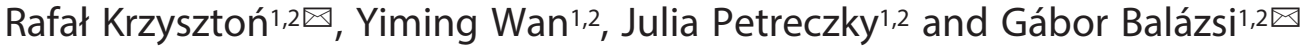 \\ 'Biomedical Engineering Department, Stony Brook University, Stony Brook, NY 11974, USA; ${ }^{2}$ The Louis \& Beatrice Laufer Center for Physical and \\ Quantitative Biology, Stony Brook University, Stony Brook, NY 11794, USA
}

Therapeutic genome modification requires precise control over the introduced therapeutic functions. Current approaches of gene and cell therapy fail to deliver such command and rely on semi-quantitative methods with limited influence on timing, contextuality and levels of transgene expression, and hence on therapeutic function. Synthetic biology offers new opportunities for quantitative functionality in designing therapeutic systems and their components. Here, we discuss synthetic biology tools in their therapeutic context, with examples of proof-of-principle and clinical applications of engineered synthetic biomolecules and higher-order functional systems, i.e. gene circuits. We also present the prospects of future development towards advanced gene-circuit therapy.

Keywords: synthetic biology, gene circuit, gene therapy, cell therapy, gene-circuit therapy, engineered therapeutics

Received: 15 June, 2021; revised: 16 June, 2021; accepted: 20 July, 2021; available on-line: 30 August, 2021

घe-mail: gabor.balazsi@stonybrook.edu (GB) Rafal.Krzyszton@ stonybrook.edu (RK)

*This paper is dedicated to Professor Wacław Tadeusz Szybalski on the 100th anniversary of his birth

Acknowledgements of Financial Support: Supported by the National Institutes of Health, NIGMS MIRA Program (R35 GM122561) by Stony Brook Cancer Center Engineering, Physical Sciences and Oncology Pilot Funds, and by the Laufer Center for Physical and Quantitative Biology.

Abbreviations: $\mathrm{ER}$, expression regulator; $\mathrm{RN}$, regulatory network; TF, transcription factor; SGC, synthetic gene circuit; SHS, safe harbor site; PDX1, the pancreatic duodenal homeobox protein; NGN3 , the neurogenin; MAFA, the V-maf musculoaponeurotic fibrosarcoma oncogene homologue $A$; RKIP, Raf kinase inhibitory protein; $\mathrm{BACH} 1$, BTB And CNC Homology 1; CAR, chimeric antigen receptor; CRISPR, Clustered Regularly Interspaced Short Palindromic Repeats; Cas9, CRISPR-associated protein 9

\section{INTRODUCTION}

Since Professor Wacław Szybalski and others pioneered stable gene transfer into mammalian cells (Szybalska \& Szybalski, 1962; Cepko et al., 1984; Neufeld et al., 1972), their efforts have been extended in many ways. Within the last six decades gene and cell therapy have reached significant milestones due to refined viral and non-viral nucleic acid delivery (Dunbar et al., 2018; Buck et al., 2019; Lai \& Wong, 2018; Lostalé-Seijo \& Montenegro, 2018) and sophisticated therapeutic strategies (Dunbar et al., 2018). However, ongoing challenges with complex diseases, such as neurodegeneration (Sun \& Roy, 2021) or cancer (Flavahan et al., 2017; DagogoJack \& Shaw, 2018), cry out for even more elegant, precise and quantitative treatment solutions.
How can we proceed to meet such superior demands? We should start by rephrasing how we describe biological systems. Let us consider cellular processes from the engineering perspective and postulate several hypotheses. First, protein and RNA synthesis in each cell are governed by a complex, dynamic and modular network of mutually-controlled expression regulators (ER), i.e. transcription factors (TFs), microRNAs, etc. (Fig. 1A). Second, this regulatory network (RN) controls metabolic processes through products of regulated effector genes. Third, the global condition of the $\mathrm{RN}$, delineated by protein levels stemming from rate constants, accessible TF-binding sites etc., impacts the health and disease of cells (Fig. 1A and 1B.I) and tissues. Finally, its dynamic, hyperlinked structure enables the $\mathrm{RN}$ to act as a cellular processing core responsible for receiving and integrating signals, propagating them outside to other cells or "making decisions" (Fig. 1A) (Balázsi et al., 2011). To illustrate the importance of these abstract concepts we will follow the differentiation stages of pancreatic $\beta$-cells.

\section{NETWORK DYNAMICS IN ACTION - DIFFERENTIATION OF PANCREATIC $\beta$-CELLS}

Found in pancreatic islets, $\beta$-cells are the endocrine cells responsible for synthesis and secretion of insulin, which controls the glucose level in the blood. Pathological autoimmune depletion of $\beta$-cells leads to insufficient insulin release and hyperglycemia in type 1 diabetes. Differentiated $\beta$-cell transplants can potentially cure type 1 diabetes and relieve patients from lifelong monitoring of glucose levels and insulin injections (Weir et al., 2011). However, differentiation of therapeutic, insulin-producing and glucose-sensitive $\beta$-cells in vitro is far from being simple. Both in vivo and in vitro, $\beta$-cell differentiation is governed by three master transcription factors: (1) the pancreatic duodenal homeobox protein PDX1, (2) the neurogenin NGN-3 and (3) the V-maf musculoaponeurotic fibrosarcoma oncogene homologue A, MAFA. Relative levels of these TFs induce vast changes in the gene expression profile and the phenotypic state of differentiating cells. Importantly, the effective transition of endoderm progenitor cells into fully mature, glucose-responsive and insulin-producing $\beta$-cells requires a well-defined temporal pattern of PDX1, NGN-3 and MAFA expression. First, an increase in PDX1 levels correlates with the transition of endoderm cells into pancreatic progenitors. Subsequently, PDX1 expression must decrease simultaneously with the upregulation of NGN-1 for pancreatic progenitors to enter the endocrine progenitor stage. Finally, a secondary increase in PDX1 levels coupled with MAFA upregulation and NGN-1 decline shifts 

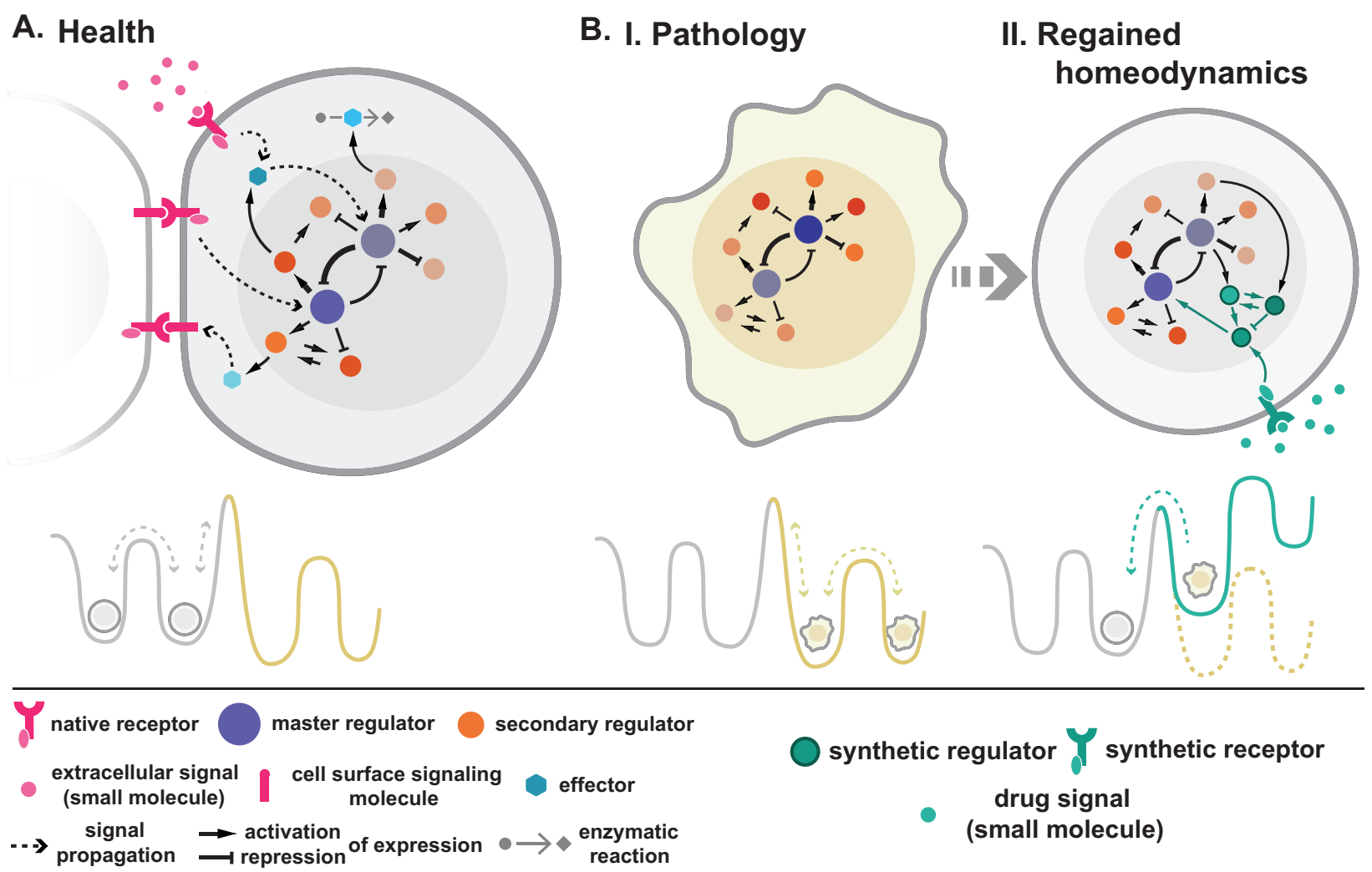

Figure 1. The dynamic regulatory network (RN) constitutes a processing core, driving cell functions.

(A.) Master regulators (i.e. transcription factors) controlling expression of multiple functional genes constitute network hubs. The protein expression levels together with reaction rates and network motifs define the global state of the RN that underlies the physiological cell states (represented as valleys in the landscape). The dynamic nature of RN function allows cells to sense internal and external signals, process them, communicate with other cells and shift into other global states according to the circumstances. (B.) I. If the cell enters a state beyond its homeodynamic capabilities (yellow region of the landscape) then it develops pathological behaviors and cannot adopt normally to external and internal cues. II. A synthetic gene circuit, with defined input, output and regulation points, can be incorporated into the native RN structure. When integrated efficiently, such a gene circuit can sense the cues characteristic to pathological states, integrate them and precisely tune crucial elements within native RN. Such changes bring the global expression profile back to its normal state.

endocrine progenitors into mature $\beta$-cells (Pagliuca et al., 2014; Saxena et al., 2016a; Habener et al., 2005). In the healthy pancreas, precise timing of these changes directs global gene expression profiles and drives the cell along a defined trajectory of sequential differentiation stages required to reach the fully mature, insulin-producing and glucose-sensitive $\beta$-cell state. However, governing the same precise cascade of events in vitro by applying growth factors and hormones without direct TF control is particularly difficult (Pagliuca et al., 2014), highlighting the need for alternate approaches.

\section{DISRUPTION IN THE NETWORK - PATHOLOGY DEVELOPMENT}

Precise control over levels of expression regulators is critical, but what happens when it is compromised? The badly timed activation of ERs and their disproportional or noisy expression can cause various cell types to enter pathological states beyond their normal capabilities to maintain homeodynamics. For instance, imbalance between the levels of Raf kinase inhibitory protein (RKIP) and metastasis activator BTB And CNC Homology 1 (BACH1) can lead to metastatic transitions in cancer due to increased expression noise and cell heterogeneity (Lee et al., 2014; Gómez Tejeda Zañudo et al., 2019). Likewise, disrupted levels of chromatin regulators may lead to exceedingly restrictive or permissive epigenetic land- scapes, consequently increasing epigenetic instability and stochastic oncogene activation (Flavahan et al., 2017). Efficient therapeutic effect requires a precise counterbalance to such pathological disruptions to bring expression profiles back to their normal physiological state (Figure 1B.II). Yet, conventional approaches of gene therapy face substantial limitations in this respect.

\section{STRUGGLES OF GENE AND CELL THERAPY}

Gene transfer lies at the foundation of gene therapy. Successful non-viral gene transfer depends on pharmacokinetics and cellular uptake of delivery agents followed by release of encapsulated nucleic acids into cells. These processes are inherently stochastic and contribute to the high heterogeneity of responses within the targeted cell population (Leonhardt et al., 2014; Schwake et al., 2010; Ligon et al., 2014). Similarly, viral delivery and natural viral infection involve substantial cell-to-cell variation (Snijder et al., 2009; Zhu et al., 2020; Mikkola et al., 2000; Brandt et al., 2020; Russell et al., 2018). Regardless of these limitations, even ideal, fully controlled gene transfer would allow for overexpression of only a few transgenes with limited command over the exact levels and kinetics of the expressed proteins. Such shortcomings are unacceptable and potentially harmful upon treatments requiring a narrow therapeutic window, precise kinetic control (Del Vecchio et al., 2017) or those that 
A. Linearizer / Noise Reducer

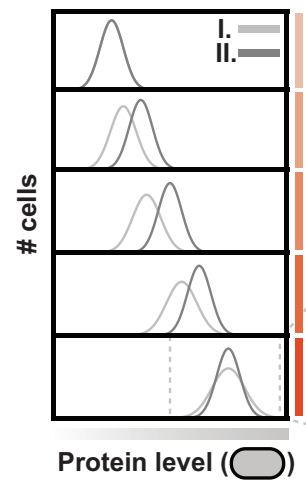

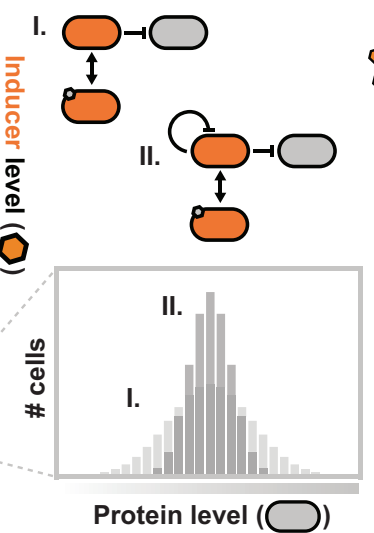

I. No Feedback



II. Negative Feedback

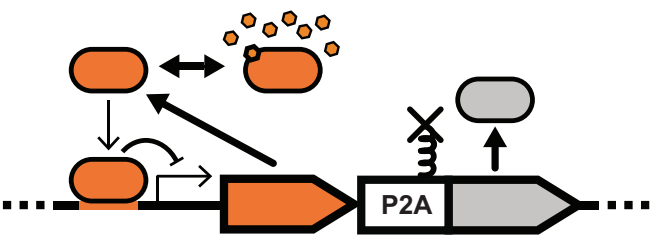

C. Mid-Range-Signal Filter

B. Toggle Switch
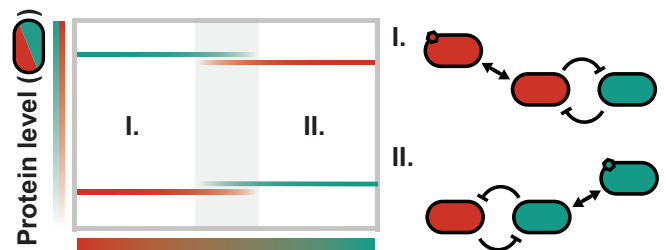

inducer $1(0)$ level $(0)$ inducer 2


II.

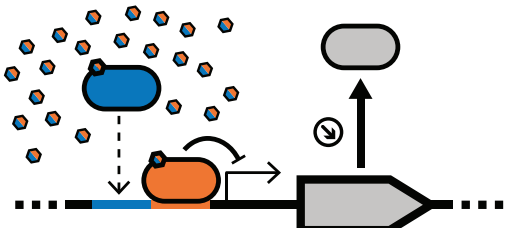

Figure 2. Examples of synthetic circuit geometries

(A.) Negative autoregulation transcriptionally coupled with an effector gene (II.) decreases the expression heterogeneity and linearizes the does-response within the cell population when compared to a dual-promoter no-feedback system (I.). The bicistronic gene in II. contains a sequence of self-cleaving linker peptide (P2A) allowing effector and regulator to split shortly after translation. (B.) The dynamics of two mutual, signal-dependent repressors allows bistability, with one or two attractors dependent on the levels of signals deactivating each of the repressors. Such bistability works like a toggle switch where the increase in one antagonistic signals trigger the corresponding stable state (I. Green signal prevails, II. Red signal prevails. The grey area represents the range of inducer levels where both stable states coexist).C. The same molecular signal activates two transcription factors, a repressor and an activator, that regulate the same effector gene. The activator has high sensitivity to the signal and low affinity to the target, causing an increase in effector concentration at low signal levels (I.). Contrarily, the low-signal-sensitivity and high-target-affinity repressor dominates over the activator and causes a decrease in effector concentration at high signal levels (II.). Such a system allows only intermediate-level signals to propagate through and constitutes a mid-range signal filter.

involve engineered therapeutic cells. For instance, T-cell immunotherapy can cause adverse effects, such as cytokine release syndrome (Lim \& June, 2017; Fitzgerald et al., 2017) due to disproportionate activation of modified T cells.

\section{SYNTHETIC BIOLOGY - BIOMOLECULAR TOOLS}

The advent of synthetic biology opened new perspectives for improved gene and cell therapy. Advances in genetic and biomolecular engineering allow the design of new, synthetic biomolecules that receive and transmit signals within living cells, triggering controlled gene expression and metabolic reactions. Newly developed functional classes of biomolecules and their fragments range from chimeric transcription factors (Garg et al., 2012; Thakore et al., 2016; Bashor et al., 2019), synthetic receptors (Morsut et al., 2016; Porter et al., 2011), RNA(Culler et al., 2010; Paek et al., 2015; Green et al., 2014), CRISPR-Cas- (Thakore et al., 2016; Esvelt et al., 2013) and light-induction-based molecular switches (Guinn \& Balázsi, 2019; Müller et al., 2015; Strickland et al., 2010), localization (Spiltoir et al., 2016; Niopek et al., 2016, 2014) and stability (Finley, 2009; Bonger et al., 2014) control factors among others (Bugaj et al., 2013; Mishra et al., 2014; Fux et al., 2021). A prominent example of synthetic biomolecules in action is within chimeric antigen receptor (CAR)-engineered T cells (Wu et al., 2020). In general, CARs constitute modified $\mathrm{T}$ cell receptors (TCR), where the engineered variable domain of a hapten-specific antibody replaces that of the TCR- $\alpha$ and/or 
- $\beta$ chains (Goverman et al., 1990; Gross et al., 1989), enabling cancer cell targeting. Such solutions exploit antigen specificity to recognize cancer cells, thus extending the spectrum of $\mathrm{T}$ cell activation beyond the capabilities of major histocompatibility complex (MHC). Development of CARs was a breakthrough in efficient $\mathrm{T}$ cell immunotherapy that is currently in clinical practice (Maude et al., 2015; Holzinger et al., 2016; Lundh et al., 2020; Lanitis et al., 2020). However, even these advanced engineered therapeutics suffer from the adverse effects of transgene overexpression, cell-cell variability, and the lack of contextual control of expression levels.

\section{SYNTHETIC BIOLOGY - NEW ADAPTIVE CELL FUNCTIONS THROUGH SYNTHETIC GENE CIRCUITS}

Recent endeavors enabled new directions towards precise and adaptive therapeutics. Largely, synthetic biomolecules are becoming highly modular and amenable to assemble into higher-order functional systems. Such systems, comprising signal transducers, receptors, mutuallyand self-controlled ERs and their effectors, constitute synthetic gene circuits (SGC) with well-defined input, output and regulation characteristics. When integrated into the genome, SGCs interface with the native regulatory network at defined junction points and provide new sense-and-response capabilities to living cells. These new functions can be tuned by activating transgenic expression adaptively, only in specific cell types and cell states or in dose-responsive manner, hence with precise quantitative control. Importantly, the functions of SGCs and their building blocks are becoming more orthogonal relative to each other and the native cellular apparatus (Briner et al., 2014; Garg et al., 2012; Esvelt et al., 2013; Thakore et al., 2016; Green et al., 2014; Roybal et al., 2016; Stanton et al., 2014; Szenk et al., 2020), potentially reducing undesired side effects. Moreover, computer-aided design and mathematical modeling of reaction kinetics allow researchers to predict and fine-tune the functions of SGCs. Likewise, analyzing the local kinetics and the global structure of the native $\mathrm{RN}$ can reveal optimal control points to maximize therapeutic effect of SGCs (Gómez Tejeda Zañudo et al., 2019; Zañudo et al., 2017). Precisely-defined and complex SGC functions include Boolean logic gates (Leisner et al., 2010), gene oscillators (Stricker et al., 2008; Toettcher et al., 2010; Elowitz \& Leibier, 2000), controllable memory buffers (Weber et al., 2007; Ajo-Franklin et al., 2007), counters (Friedland et al., 2009), and spatiotemporal pattern generators (Cao et al., 2016). Signal-sensitive, self-repressing TFs reduce the expression noise of co-expressed effector proteins, lead to linear dose-response and more uniform expression profiles within cell populations when compared to their non-self-regulated equivalents (Fig. 2A) (Guinn \& Balázsi, 2019; Nevozhay et al., 2009; Nevozhay et al., 2013). Two signal-dependent, mutually repressing TFs form a toggle switch that could serve as a bistable long-term memory unit (Fig. 2B) (Kramer et al., 2004; Gardner et al., 2000).

\section{GENE-CIRCUIT THERAPY - PROOF-OF-PRINCIPLE}

Many of these and other gene circuit designs have already demonstrated their practical utility. For instance, combining two antagonistic gene regulators of different target affinity and signal sensitivity (high sensitivity, low affinity activator and low sensitivity high affinity repressor) acting on the same effector gene constitutes a mid-range-signal filter (Fig. 2C) (Greber \& Fussenegger, 2010). A lineage-control gene circuit based on a vanillic-acid-driven mid-range-signal filter succeeded in driving pancreatic $\beta$-cell differentiation by controlling the desired cascade of PDX1, NGN3 and MAFA expression. Transient transfection of human induced pluripotent stem cells (hIPSCs) with the lineage-control circuit yielded mature beta-cell differentiation with unparalleled efficiency, largely exceeding the abilities of prior methods (Saxena et al., 2016a). On-switches responding to low molecular weight drugs combined with CARs enable tunable, spatiotemporal control over activation of engineered T-cells in attempts to restrain the adverse effects of gene overexpression on CAR T-cell based immunotherapy (Wu et al., 2015). Moreover, CAR-T cell therapy can be augmented by engineering tumor cells in situ to gain an immunomodulatory function (Nissim et al., 2017). SGCs can introduce novel functions into many other engineered therapeutic cells. Grafts of engineered, gene-circuit-bearing cells were instrumental in treating mouse models of obesity, metabolic syndrome, Graves' disease and gout (Rössger et al., 2013; Ye et al., 2013; Kemmer et al., 2010; Saxena et al., 2016b).

\section{GENE-CIRCUIT THERAPY - CHALLENGES AND HOW TO FACE THEM}

While promising, synthetic gene circuits still have many obstacles to overcome on their way to the clinic. The biggest shortcomings in designing efficient gene-circuit therapy for systemic applications are adverse off-target effects. Like for conventional gene therapy, effective strategies require specific targeting into the cells of interest, avoiding cytotoxic effects and adverse immune system activation. Most importantly however, SGCs need to be incorporated into safe genomic loci that facilitate full functionality and avoid any unwanted, potentially oncogenic genome alterations (Markstein et al., 2008; Liebert \& Ellis, 2005; Russell \& Grompe, 2015; Bestor, 2000). All these considerations demand precise and selective delivery and integration strategies. The CRISPR-Cas9 system offers a tempting alternative over semi-random viral genome editing. Programmable integration into predefined chromosome regions, improved specificity (Briner et al., 2014; Kocak et al., 2019) and ever-expanding modes of genome editing by different classes of CRISPR-Cas9-derived editing agents (Anzalone et al., 2020) are the main advantages of the system. However, reports on off-target insertions caused by CRISPR-Cas9 system and immunogenicity of CRISPR-Cas9 components remain concerning and need to be carefully addressed (Anzalone et al., 2020; Zhang et al., 2015; Dai et al., 2016). Independently of genome editing, systematic studies have revealed sets of human "safe harbor sites" (SHS), that are genomic regions with minimal potential for transgene deactivation and unwanted deregulation of native regulatory network upon transgene integration (Sadelain et al., 2012; Papapetrou \& Schambach, 2016; Pellenz et al., 2019; Gaidukov et al., 2018). The exploration of the full therapeutic potential of SHSs is still ahead. Moreover, the use of orthogonal site-specific recombinases, like Flp or Cre, combined with CRISPR-Cas9 methods can further improve the site-specificity of construct insertion. For example, CRISPR-Cas9 could integrate prerequisite recognition sites of a site-specific recombinase (a so-called "landing pad") into the SHS, allowing subsequent modification through recombinase-mediated cassette exchange (RMCE) (Duportet et al., 2014; Ordovás 
et al., 2015). Since site-specific recombinases do not create double strand breaks in chromosomal DNA and are restrictively specific to their own recognition sites, these approaches are promising to minimize off-target insertions (Grindley et al., 2006; Ma et al., 2014). Further advance are prospectively possible by using transient "integrator" gene circuits where the expression of CRISPRCas9 machinery and recombinase of choice is adjusted to achieve maximal integration efficiency without adverse side effects. Other extensions can include "safety switch" designs (Kiani et al., 2015) that limit the integration only to the cells of interest, supporting current methods of targeted gene delivery (Lostalé-Seijo \& Montenegro, 2018). Other approaches, such as self-replicating RNA circuits and non-integrative viral vectors, are also promising (Wagner et al., 2018; Schlaeger et al., 2015)

\section{CONCLUSION}

As Professor Wacław Szybalski predicted in the 1974 proceedings book "Control of Gene Expression" (Szybalski, 1974) we have entered into the era of engineered and synthetic biology. Examples and strategies presented in this review constitute the first steps in the new direction of engineered therapeutics and gene circuit therapy, sparking new anticipation and hope. For instance, the current expansion of the field of protein design and the progress in understanding of dynamic gene regulation are highly promising for future treatment strategies. Yet, there is still much to be done.

\section{REFERENCES}

Ajo-Franklin CM, Drubin DA, Eskin JA, Gee EPS, Landgraf D, Phillips I, Silver PA (2007) Rational design of memory in eukaryotic cells. Genes Dev. 21: 2271-2276. https://doi.org/10.1101/ gad.1586107

Anzalone A V., Koblan LW, Liu DR (2020) Genome editing with CRISPR-Cas nucleases, base editors, transposases and prime editors. Nat. Biotechnol. 38: 824-844. https://doi.org/10.1038/s41587020-0561-9

Balázsi G, Van Oudenaarden A, Collins JJ (2011) Cellular decision making and biological noise: From microbes to mammals. Cell 144: 910-925. https://doi.org/10.1016/j.cell.2011.01.030

Bashor CJ, Patel N, Choubey S, Beyzavi A, Kondev J, Collins JJ, Khalil AS (2019) Complex signal processing in synthetic gene circuits using cooperative regulatory assemblies. Science (80-.). 364: https:// doi.org/10.1126/science.aau8287

Bestor TH (2000) Gene silencing as a threat to the success of gene therapy. J. Clin. Invest. 105: 409-411. https://doi.org/10.1172/ JCI9459

Bonger KM, Rakhit R, Payumo AY, Chen JK, Wandless TJ (2014) General method for regulating protein stability with light. ACS Chem. Biol. 9: 111-115. https://doi.org/10.1021/cb400755

Brandt L, Cristinelli S, Ciuffi A (2020) Single-cell analysis reveals heterogeneity of virus infection, pathogenicity, and host responses: HIV as a pioneering example. Annu. Rev. Virol. 7: 333-350. https://doi. org/10.1146/annurev-virology-021820-102458

Briner AE, Donohoue PD, Gomaa AA, Selle K, Slorach EM, Nye CH, Haurwitz RE, Beisel CL, May AP, Barrangou R (2014) Short article guide RNA functional modules direct Cas 9 activity and orthogonality. Mol. Cell 56: 333-339. https://doi.org/10.1016/j.molcel.2014.09.019

Buck J, Grossen P, Cullis PR, Huwyler J, Witzigmann D (2019) Lipidbased DNA therapeutics: Hallmarks of non-viral gene delivery. ACS Nano 13: 3754-3782. https://doi.org/10.1021/acsnano.8b07858

Bugaj LJ, Choksi AT, Mesuda CK, Kane RS, Schaffer DV (2013) Optogenetic protein clustering and signaling activation in mammalian cells. Nat. Methods 10: 249-252. https://doi.org/10.1038/ nmeth. 2360

Cao Y, Ryser MD, Payne S, Li B, Rao C V, You L (2016) Collective space-sensing coordinates pattern scaling in engineered bacteria. Cell 165: 620-630. https://doi.org/10.1016/j.cell.2016.03.006

Cepko CL, Roberts BE, Mulligan RC (1984) Construction and applications of a highly transmissible murine retrovirus shuttle vector. Cell 37: 1053-1062. https://doi.org/10.1016/0092-8674(84)90440-9
Culler SJ, Hoff KG, Smolke CD (2010) Reprogramming cellular behavior with RNA controllers responsive to endogenous proteins. Science (80-.). 330: 1251-1255. https://doi.org/10.1126/science.1192128

Dagogo-Jack I, Shaw AT (2018) Tumour heterogeneity and resistance to cancer therapies. Nat. Rev. Clin. Oncol. 15: 81-94. https://doi. org/10.1038/nrclinonc.2017.166

Dai WJ, Zhu LY, Yan ZY, Xu Y, Wang QL, Lu XJ (2016) CRISPRCas9 for in vivo gene therapy: promise and hurdles. Mol. Ther. $-\mathrm{Nu}$ cleic Acids 5: e349. https://doi.org/10.1038/mtna.2016.58

Dunbar CE, High KA, Joung JK, Kohn DB, Ozawa K, Sadelain M (2018) Gene therapy comes of age. Science (80-.). 359: https://doi. org $/ 10.1126 /$ science.aan 4672

Duportet X, Wroblewska L, Guye P, Li Y, Eyquem J, Rieders J, Rimchala T, Batt G, Weiss R (2014) A platform for rapid prototyping of synthetic gene networks in mammalian cells. Nucleic Acids Res. 42: 13440-13451. https://doi.org/10.1093/nar/gku1082

Elowitz MB, Leibier S (2000) A synthetic oscillatory network of transcriptional regulators. Nature 403: https://doi.org/10.1038/35002125

Esvelt KM, Mali P, Braff JL, Moosburner M, Yaung SJ, Church GM (2013) Orthogonal Cas 9 proteins for RNA-guided gene regulation and editing. Nat. Methods 10: 1116-1123. https://doi.org/10.1038/ nmeth. 2681

Finley D (2009) Recognition and processing of ubiquitin-protein conjugates by the proteasome. Annu. Rev. Biochem. 78: 477-513. https:// doi.org/10.1146/annurev.biochem.78.081507.101607

Fitzgerald JC, Weiss SL, Maude SL, Barrett DM, Lacey SF, Melenhorst JJ, Shaw P, Berg RA, June CH, Porter DL, Frey NV, Grupp SA, Teachey DT (2017) Cytokine release syndrome after chimeric antigen receptor $\mathrm{T}$ cell therapy for acute lymphoblastic leukemia. Crit. Care Med. 45: e124-e125. https://doi.org/10.1097/ CCM.0000000000002053

Flavahan WA, Gaskell E, Bernstein BE (2017) Epigenetic plasticity and the hallmarks of cancer. Science (80-.). 357: https://doi.org/10.1126/ science.aal 2380

Friedland AE, Lu TK, Wang X, Shi D, Church G, Collins JJ (2009) Synthetic gene networks that count. Science (80-.). 324: https://doi. org/10.1126/science.1172005

Fux C, Moser S, Schlatter S, Rimann M, Bailey JE, Fussenegger M (2021) Streptogramin- And tetracycline-responsive dual regulated expression of $\mathrm{p} 27 \mathrm{Kip} 1$ sense and antisense enables positive and negative growth control of Chinese hamster ovary cells. Nucleic Acids Res. 29: 1-7. https://doi.org/10.1093/nar/29.4.e19

Gaidukov L, Wroblewska L, Teague B, Nelson T, Zhang X, Liu Y, Jagtap K, Mamo S, Allen Tseng W, Lowe A, Das J, Bandara K, Baijuraj S, Summers NM, Lu TK, Zhang L, Weiss R (2018) A multi-landing pad DNA integration platform for mammalian cell engineering. Nucleic Acids Res. 46: 4072-4086. https://doi.org/10.1093/ nar/gky216

Gardner TS, Cantor CR, Collins JJ (2000) Construction of a genetic toggle switch in Escherichia coli. Nature 403: 339-342. https://doi. org/10.1038/35002131

Garg A, Lohmueller JJ, Silver PA, Armel TZ (2012) Engineering synthetic TAL effectors with orthogonal target sites. Nucleic Acids Res. 40: 7584-7595. https://doi.org/10.1093/nar/gks404

Gómez Tejeda Zañudo J, Guinn MT, Farquhar K, Szenk M, Steinway SN, Balázsi G, Albert R (2019) Towards control of cellular decision-making networks in the epithelial-to-mesenchymal transition. Phys. Biol. 16: https://doi.org/10.1088/1478-3975/aaffa1

Goverman J, Gomez SM, Segesman KD, Hunkapiller T, Laug WE, Hood L (1990) Chimeric immunoglobulin-T cell receptor proteins form functional receptors: Implications for $\mathrm{T}$ cell receptor complex formation and activation. Cell 60: 929-939. https://doi. org/10.1016/0092-8674(90)90341-B

Greber D, Fussenegger M (2010) An engineered mammalian band-pass network. Nucleic Acids Res. 38: https://doi.org/10.1093/nar/gkq671

Green AA, Silver PA, Collins JJ, Yin P (2014) Toehold switches: Denovo-designed regulators of gene expression. Cell 159: 925-939. https://doi.org/10.1016/j.cell.2014.10.002

Grindley NDF, Whiteson KL, Rice PA (2006) Mechanisms of sitespecific recombination. Annu. Rev. Biochem. 75: 567-605. https://doi. org/10.1146/annurev.biochem.73.011303.073908

Gross G, Waks T, Eshhar Z (1989) Expression of immunoglobulinT-cell receptor chimeric molecules as functional receptors with antibody-type specificity. Proc. Natl. Acad. Sci. U. S. A. 86: 10024 10028. https://doi.org/10.1073/pnas.86.24.10024

Guinn MT, Balázsi G (2019) Noise-reducing optogenetic negative-feedback gene circuits in human cells. Nucleic Acids Res. 47: 7703-7714. https://doi.org/10.1093/nar/gkz556

Habener JF, Kemp DM, Thomas MK (2005) Minireview : Transcriptional regulation in pancreatic development. 146: 1025-1034. https://doi.org/10.1210/en.2004-1576

Holzinger A, Barden M, Abken H (2016) The growing world of CAR $\mathrm{T}$ cell trials: a systematic review. Cancer Immunol. Immunother. 65: 1433-1450. https://doi.org/10.1007/s00262-016-1895-5

Kemmer C, Gitzinger M, Baba MD, Djonov V, Stelling J, Fussenegger M (2010) Self-sufficient control of urate homeostasis in mice 
by a synthetic circuit. Nat. Biotechnol. 28: 355-361. https://doi. org $/ 10.1038 /$ nbt.1617

Kiani S, Chavez A, Tuttle M, Hall RN, Chari R, Ter-Ovanesyan D, Qian J, Pruitt BW, Beal J, Vora S, Buchthal J, Kowal EJK, Ebrahimkhani MR, Collins JJ, Weiss R, Church G (2015) Cas9 gRNA engineering for genome editing, activation and repression. Nat. Methods 12: 1051-1054. https://doi.org/10.1038/nmeth.3580

Kocak DD, Josephs EA, Bhandarkar V, Adkar SS, Kwon JB, Gersbach CA (2019) Increasing the specificity of CRISPR systems with engineered RNA secondary structures. Nat. Biotechnol. 37: 657-666. https://doi.org/10.1038/s41587-019-0095-1

Kramer BP, Viretta AU, Baba MD, Aubel D, Weber W, Fussenegger M (2004) An engineered epigenetic transgene switch in mammalian cells. 22: 867-870. https://doi.org/10.1038/nbt980

Lai WF, Wong WT (2018) Design of polymeric gene carriers for effective intracellular delivery. Trends Biotechnol. 36: 713-728. https://doi. org/10.1016/j.tibtech.2018.02.006

Lanitis E, Coukos G, Irving M (2020) All systems go: converging synthetic biology and combinatorial treatment for CAR-T cell therapy. Curr. Opin. Biotechnol. 65: 75-87. https://doi.org/10.1016/j.copbio.2020.01.009

Lee J, Lee J, Farquhar KS, Yun J, Frankenberger CA, Bevilacqua E, Yeung K, Kim EJ, Balázsi G, Rosner MR (2014) Network of mutually repressive metastasis regulators can promote cell heterogeneity and metastatic transitions. Proc. Natl. Acad. Sci. U. S. A. 111: https://doi.org/10.1073/pnas.1304840111

Leisner M, Bleris L, Lohmueller J, Xie Z, Benenson Y (2010) Rationally designed logic integration of regulatory signals in mammalian cells. Nat. Nanotechnol. 5: 666-670. https://doi.org/10.1038/nnano. 2010.135

Leonhardt C, Schwake G, Stögbauer TR, Rappl S, Kuhr J-T, Ligon TS, Rädler JO (2014) Single-cell mRNA transfection studies: delivery, kinetics and statistics by numbers. Nanomedicine 10: 679-88. https:// doi.org/10.1016/j.nano.2013.11.008

Liebert MA, Ellis J (2005) Silencing and variegation of gammaretrovirus and lentivirus vectors. 1246: 1241-1246

Ligon TS, Leonhardt C, Rädler JO (2014) Multi-level kinetic model of mRNA delivery via transfection of lipoplexes. PLoS One 9: https:// doi.org/10.1371/journal.pone.0107148

Lim WA, June CH (2017) Review the principles of engineering immune cells to treat cancer. Cell 168: 724-740. https://doi.org/10.1016/j. cell.2017.01.016

Lostalé-Seijo I, Montenegro J (2018) Synthetic materials at the forefront of gene delivery. Nat. Rev. Chem. 2: 258-277. https://doi. org/10.1038/s41570-018-0039-1

Lundh S, Young I, Dimitri A, Vora A, Melenhorst JJ, Jadlowsky JK, Fraietta JA (2020) Clinical practice : chimeric antigen receptor (CAR) $\mathrm{T}$ cells: a major breakthrough in the battle against cancer. Clin. Exp. Med. 20: 469-480. https://doi.org/10.1007/s10238-02000628-1

Ma CH, Liu YT, Savva CG, Rowley PA, Cannon B, Fan HF, Russell R, Holzenburg A, Jayaram M (2014) Organization of DNA partners and strand exchange mechanisms during flp site-specific recombination analyzed by difference topology, single molecule FRET and single molecule TPM. J. Mol. Biol. 426: 793-815. https://doi. org/10.1016/j.jmb.2013.11.017

Markstein M, Pitsouli C, Villalta C, Celniker SE, Perrimon N (2008) Exploiting position effects and the gypsy retrovirus insulator to engineer precisely expressed transgenes. Nat. Genet. 40: 476-483. https://doi.org/10.1038/ng.101

Maude SL, Teachey DT, Porter DL, Grupp SA (2015) CD19-targeted chimeric antigen receptor T-cell therapy for acute lymphoblastic leukemia. 125: 4017-4023. https://doi.org/10.1182/ blood-2014-12-580068.

Mikkola H, Woods N-B, Sjögren M, Helgadottir H, Hamaguchi I, Jacobsen S-E, Trono D, Karlsson S (2000) Lentivirus gene transfer in murine hematopoietic progenitor cells is compromised by a delay in proviral integration and results in transduction mosaicism and heterogeneous gene expression in progeny cells. J. Virol. 74: 11911-11918. https://doi.org/10.1128/jvi.74.24.11911-11918.2000

Mishra D, Rivera PM, Lin A, Del Vecchio D, Weiss R (2014) A load driver device for engineering modularity in biological networks. Nat. Biotechnol. 32: 1268-1275. https://doi.org/10.1038/nbt.3044

Morsut L, Roybal KT, Gordley RM, Coyle SM, Thomson M, Lim WA (2016) Engineering customized cell sensing and response behaviors using synthetic notch receptors. Cell 164: 780-791. https://doi. org/10.1016/i.cell.2016.01.012

Müller K, Zurbriggen MD, Weber W (2015) An optogenetic upgrade for the Tet-OFF system. Biotechnol. Bioeng. 112: 1483-1487. https:// doi.org/10.1002/bit.25562

Neufeld EF, Sweeley CC, Rogers S, Friedmann T, Roblin R (1972) Gene therapy for human genetic disease? Science (80-.). 178: 648649. https://doi.org/10.1126/science.178.4061.648

Nevozhay D, Adams RM, Murphy KF, Josić K, Balázsi G (2009) Negative autoregulation linearizes the dose-response and suppresses the heterogeneity of gene expression. Proc. Natl. Acad. Sci. U. S. A. 106: 5123-5128. https://doi.org/10.1073/pnas.0809901106

Nevozhay D, Zal T, Balázsi G (2013) Transferring a synthetic gene circuit from yeast to mammalian cells. Nat. Commun. 4: 1-11. https:// doi.org/10.1038/ncomms2471

Niopek D, Benzinger D, Roensch J, Draebing T, Wehler P, Eils R, Di Ventura B (2014) Engineering light-inducible nuclear localization signals for precise spatiotemporal control of protein dynamics in living cells. Nat. Commun. 5: https://doi.org/10.1038/ncomms5404

Niopek D, Wehler P, Roensch J, Eils R, Di Ventura B (2016) Optogenetic control of nuclear protein export. Nat. Commun. 7: 1-9. https://doi.org/10.1038/ncomms10624

Nissim L, Wu M, Pery E, Tabach Y, Sharp PA, Lu TK, Nissim L, Wu M, Pery E, Binder-nissim A, Suzuki HI, Stupp D, Wehrspaun C (2017) Synthetic RNA-based immunomodulatory gene circuits for cancer immunotherapy. Cell 171: 1138-1142.e15. https://doi. org/10.1016/j.cell.2017.09.049

Ordovás L, Boon R, Pistoni M, Chen Y, Wolfs E, Guo W, Sambathkumar R, Bobis-Wozowicz S, Helsen N, Vanhove J, Berckmans P, Cai Q, Vanuytsel K, Eggermont K, Vanslembrouck V, Schmidt BZ, Raitano S, Van Den Bosch L, Nahmias Y, Cathomen T, Struys T, Verfaillie CM (2015) Efficient recombinase-mediated cassette exchange in hPSCs to study the hepatocyte lineage reveals AAVS1 locus-mediated transgene inhibition. Stem Cell Reports 5: 918-931. https://doi.org/10.1016/j.stemcr.2015.09.004

Paek KY, Hong KY, Ryu I, Park SM, Keum SJ, Kwon OS, Jang SK (2015) Translation initiation mediated by RNA looping. Proc. Natl. Acad. Sci. U. S. A. 112: 1041-1046. https://doi.org/10.1073/ pnas.1416883112

Pagliuca FW, Millman JR, Gürtler M, Segel M, Van Dervort A, Ryu JH, Peterson QP, Greiner D, Melton DA (2014) Generation of functional human pancreatic $\beta$ cells in vitro. Cell 159: 428-439. https://doi.org/10.1016/j.cell.2014.09.040

Papapetrou EP, Schambach A (2016) Gene insertion into genomic safe harbors for human gene therapy. Mol. Ther. 24: 678-684. https:// doi.org/10.1038/mt.2016.38

Pellenz S, Phelps M, Tang W, Hovde BT, Sinit RB, Fu W, Li H, Chen E, Monnat RJ (2019) New human chromosomal sites with 'safe harbor' potential for targeted transgene insertion. Hum. Gene Ther. 30: 814-828. https://doi.org/10.1089/hum.2018.169

Porter DL, Levine BL, Kalos M, Bagg A, June CH (2011) Chimeric antigen receptor-modified $\mathrm{T}$ cells in chronic lymphoid leukemia. $\mathrm{N}$. Engl. J. Med. 365: 725-733. https://doi.org/10.1056/nejmoa1103849

Rössger K, Charpin-El-Hamri G, Fussenegger M (2013) A closed-loop synthetic gene circuit for the treatment of diet-induced obesity in mice. Nat. Commun. 4: 1-9. https://doi.org/10.1038/ncomms3825

Roybal KT, Rupp LJ, Morsut L, Walker WJ, Mcnally KA, Park JS, Lim WA, Roybal KT, Rupp LJ, Morsut L, Walker WJ, Mcnally KA, Park JS (2016) Precision tumor recognition by $\mathrm{T}$ cells with article precision tumor recognition by $\mathrm{T}$ cells with combinatorial antigen-sensing circuits. Cell 164: 770-779. https://doi.org/10.1016/j. cell.2016.01.011

Russell AB, Trapnell C, Bloom JD (2018) Extreme heterogeneity of influenza virus infection in single cells. Elife 7: 1-26. https://doi. org/10.7554/eLife.32303

Russell DW, Grompe M (2015) Adeno-associated virus finds its disease. Nat. Genet. 47: 1104-1105. https://doi.org/10.1038/ng.3407

Sadelain M, Papapetrou EP, Bushman FD (2012) Safe harbours for the integration of new DNA in the human genome. Nat. Rev. Cancer 12: 51-58. https://doi.org/10.1038/nrc3179

Saxena P, Heng BC, Bai P, Folcher M, Zulewski H, Fussenegger M (2016a) A programmable synthetic lineage-control network that differentiates human IPSCs into glucose-sensitive insulin-secreting beta-like cells. Nat. Commun. 7: 1-14. https://doi.org/10.1038/ ncomms 11247

Saxena P, Hamri GC El, Folcher M, Zulewski H, Fussenegger M (2016b) Synthetic gene network restoring endogenous pituitarythyroid feedback control in experimental Graves' disease. Proc. Natl. Acad. Sci. U. S. A. 113: 1244-1249. https://doi.org/10.1073/ pnas. 1514383113

Schlaeger TM, Daheron L, Brickler TR, Entwisle S, Chan K, Cianci A, DeVine A, Ettenger A, Fitzgerald K, Godfrey M, Gupta D, McPherson J, Malwadkar P, Gupta M, Bell B, Doi A, Jung N, Li X, Lynes MS, Brookes E, Cherry AB, Demirbas D, Tsankov AM, Zon LI, Rubin LL, Feinberg AP, Meissner A, Cowan CA, Daley GQ (2015) A comparison of non-integrating reprogramming methods. Nat. Biotechnol. 33: 58-63. https://doi.org/10.1038/nbt.3070

Schwake G, Youssef S, Kuhr J-T, Gude S, David MP, Mendoza E, Frey E, Rädler JO (2010) Predictive modeling of non-viral gene transfer. Biotechnol. Bioeng. 105: 805-813. https://doi.org/10.1002/ bit. 22604

Snijder B, Sacher R, Rämö P, Damm E-M, Liberali P, Pelkmans L (2009) Population context determines cell-to-cell variability in endocytosis and virus infection. Nature 461: 520-523. https://doi. org/10.1038/nature08282 
Spiltoir JI, Strickland D, Glotzer M, Tucker CL (2016) Optical control of peroxisomal trafficking. ACS Synth. Biol. 5: 554-560. https://doi. org/10.1021/acssynbio.5b00144

Stanton BC, Siciliano V, Ghodasara A, Wroblewska L, Clancy K, Trefzer AC, Chesnut JD, Weiss R, Voigt CA (2014) Systematic transfer of prokaryotic sensors and circuits to mammalian cells. ACS Synth. Biol. 3: 880-891. https://doi.org/10.1021/sb5002856

Stricker J, Cookson S, Bennett MR, Mather WH, Tsimring LS, Hasty J (2008) A fast, robust and tunable synthetic gene oscillator. Nature 456: 516-519. https://doi.org/10.1038/nature07389

Strickland D, Yao X, Gawlak G, Rosen MK, Gardner KH, Sosnick TR (2010) Rationally improving LOV domainĝ€’'based photoswitches. Nat. Methods 7: 623-626. https://doi.org/10.1038/nmeth.1473

Sun J, Roy S (2021) Gene-based therapies for neurodegenerative diseases. Nat. Neurosci. 24: 297-311. https://doi.org/10.1038/s41593020-00778-1

Szenk M, Yim T, Balázsi G (2020) Multiplexed gene expression tuning with orthogonal synthetic gene circuits. ACS Synth. Biol. 9: 930-939. https://doi.org/10.1021/acssynbio.9b00534

Szybalska EH, Szybalski W (1962) Genetics of human cess line. IV. DNA-mediated heritable transformation of a biochemical trait. Proc. Natl. Acad. Sci. U. S. A. 48: 2026-2034. https://doi.org/10.1073/ pnas.48.12.2026

Szybalski W (1974) In vivo and in vitro initiation of transcription. $A d v$. Exp. Med. Biol. 44: 23-24. https://doi.org/10.1007/978-1-46843246-6_3

Thakore PI, Black JB, Hilton IB, Gersbach CA (2016) Editing the epigenome: technologies for programmable transcription and epigenetic modulation. 13: 127-137. https://doi.org/10.1038/nmeth.3733

Toettcher JE, Mock C, Batchelor E, Loewer A, Lahav G (2010) A synthetic-natural hybrid oscillator in human cells. Proc. Natl. Acad. Sci. U. S. A. 107: 17047-17052. https://doi.org/10.1073/ pnas. 1005615107

Del Vecchio D, Abdallah H, Qian Y, Collins JJ (2017) A Blueprint for a synthetic genetic feedback controller to reprogram cell fate. Cell Syst. 4: 109-120.e11. https://doi.org/10.1016/j.cels.2016.12.001

Wagner TE, Becraft JR, Bodner K, Teague B, Zhang X, Woo A, Porter E, Alburquerque B, Dobosh B, Andries O, Sanders NN, Beal
J, Densmore D, Kitada T, Weiss R (2018) Small-molecule-based regulation of RNA-delivered circuits in mammalian cells. Nat. Chem. Biol. 14: 1043-1050. https://doi.org/10.1038/s41589-018-0146-9

Weber W, Stelling J, Rimann M, Keller B, Daoud-El Baba M, Weber CC, Aubel D, Fussenegger M (2007) A synthetic time-delay circuit in mammalian cells and mice. Proc. Natl. Acad. Sci. U. S. A. 104: 2643-2648. https://doi.org/10.1073/pnas.0606398104

Weir GC, Cavelti-Weder C, Bonner-Weir S (2011) Stem cell approaches for diabetes: Towards beta cell replacement. Genome Med. 3: https://doi.org/10.1186/gm277

Wu CY, Roybal KT, Puchner EM, Onuffer J, Lim WA (2015) Remote control of therapeutic $\mathrm{T}$ cells through a small molecule-gated chimeric receptor. Science (80-.). 350: https://doi.org/10.1126/science. aab4077

Wu L, Wei Q, Brzostek J, Gascoigne NRJ (2020) Signaling from T cell receptors (TCRs) and chimeric antigen receptors (CARs) on T cells. Cell. Mol. Immunol. 17: 600-612. https://doi.org/10.1038/s41423020-0470-3

Ye H, Charpin-El Hamri G, Zwicky K, Christen M, Folcher M, Fussenegger M (2013) Pharmaceutically controlled designer circuit for the treatment of the metabolic syndrome. Proc. Natl. Acad. Sci. U. S. A. 110: 141-146. https://doi.org/10.1073/pnas.1216801110

Zañudo JGT, Yang G, Albert R, Levine H (2017) Structure-based control of complex networks with nonlinear dynamics. Proc. Natl. Acad. Sci. U. S. A. 114: 7234-7239. https://doi.org/10.1073/ pnas.1617387114

Zhang X, Tee LY, Wang X, Huang Q, Yang S (2015) Off-target effects in CRISPR/Cas9-mediated genome engineering. https://doi. org/10.1038/mtna.2015.37

Zhu D, Rostami MR, Zuo WL, Leopold PL, Crystal RG (2020) Singlecell transcriptome analysis of mouse liver cell-specific tropism and transcriptional dysregulation following intravenous administration of AAVrh.10 Vectors. Hum. Gene Ther. 31: 590-604. https://doi. org/10.1089/hum.2019.366 